\begin{tabular}{|c|c|c|}
\hline & Int.J.Curr.Microbiol.App.Sci (2016) 5(11): 65-73 & \multirow{4}{*}{ 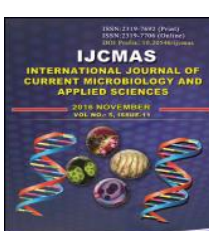 } \\
\hline & International Journal of Current Microbiology and Applied Sciences & \\
\hline & ISSN: 2319-7706 Volume 5 Number 11 (2016) pp. 65-73 & \\
\hline EXCELLENT & Journal homepage: http://www.ijcmas.com & \\
\hline PUBLISHERS & & www:ijemas,com \\
\hline
\end{tabular}

Original Research Article

http://dx.doi.org/10.20546/ijcmas.2016.511.007

\title{
Potential MIC of Bioactive Peptides from Fermented Bovine Milk to Inhibit Bacterial Pathogens
}

\author{
Garima Bhardwaj ${ }^{\text {** }}$ and Bhagat Singh ${ }^{2}$ \\ ${ }^{1}$ Research Scholar, Mewar University Rajasthan, India \\ ${ }^{2}$ College of Paramedical Sciences, U.P. University of Medical Sciences Campus, \\ Saifai Etawah, U.P. 206130, India \\ *Corresponding author
}

\section{Keywords \\ Antimicrobial peptide, Casein bioactive peptides, fermented milk peptides.}

\section{Article Info}

Accepted:

04 October 2016

Available Online:

10 November 2016

\section{A B S T R A C T}

Bovine milk proteins have been identified that possess broad spectrum antimicrobial activity. In vitro, these proteins upon degradation by digestive enzymes or microbial enzymes have been shown to release antimicrobial peptides (AMPs), which exhibit unique mechanism for killing bacteria compared with current antibiotics. These AMPs selectively binds to the outer lipid membrane of the bacterium and form blisters and pores, which eventually result in lyses of the cell leading to cellular death. Present research has been carried out to find out the minimal inhibitory effect of peptide released during fermentation under controlled condition on Staphylococcus aureus and Escherichia coli. Bioactive peptides generated during fermentation were separated using different techniques and tested for antimicrobial activity. These peptides first purified with gel filtration technique and then subjected to reverse phase high performance liquid chromatography. Broth dilution and well diffusion methods were used to determine the lowest concentration of antimicrobial peptides agent (minimal inhibitory concentration, MIC) that can inhibit the growth of selected pathogen; we find that under defined test conditions, AMPs inhibits the visible growth of the bacterium being investigated. This study demonstrated that bioactive peptides having antimicrobial acitivity generated during fermentation with $L$. helveticus showed a minimum of $8 \mathrm{~mm}$ zone of inhibition against gram positive $S$. aureus and $9 \mathrm{~mm}$ against gram negative $E$. coli on plates containing $20 \mu 1$ peptide concentration as compared to respective plates or broth tubes which determines the lowest concentration of the assayed antimicrobial peptide, minimal inhibitory concentration, (MIC). The amount of peptide as calculated for $20 \mu \mathrm{l}$ peptide suspension was $0.34 \mathrm{mg} / \mathrm{ml}$. Therefore we can conclude that $0.34 \mathrm{mg} / \mathrm{ml}$ of may be considered as minimal inhibitory concentration for the inhibition of growth of $S$. aureus and E. coli. Further study and animal trials must be carried out to decide final dose of such peptide to be used for therapeutic agent or as in food preservation.

\section{Introduction}

Bioactive peptides are defined as specific protein fragments that have a positive impact on the functioning or conditions of living beings, thereby improving their health (Korhonen and Pihlanto, 2006). The beneficial effects are attributed to different properties found in peptides such as 
antimicrobial (Rajanbabu and Chen, 2011; Bhagat Singh et al., 2012), antioxidant (Bhagat Singh and Rattan Chand, 2006; Sarmadi and Ismail, 2010), antithrombotic (Wang and Ng, 1999), anti-hypertensive (Erdmann, 2008) and immunomodulatory activities (Gauthier et al., 2006), among others. Food safety is a growing concern of great importance worldwide. Recently, the estimated costs of diseases caused by food borne pathogens was about $\$ 152$ billion in the United States (Scharff, 2010), The consumption of processed foods with chemical preservatives has led to increased consumer concern and the demand for more natural and minimally processed foods. As a result, researchers have shown a growing interest in natural antimicrobial agents such as certain peptides. The value of proteins as an essential source of amino acids is well documented, but recently it has been recognized that dietary proteins exert many other functionalities in vivo by means of biologically active peptides (Agyei, 2011) A number of bioactive peptides have been identified in milk proteins, such as casein and whey proteins, where they are present in an encrypted form, stored as propeptides or mature C-terminal peptides that are only released upon proteolysis (Gobbetti et al., 2002; Kamysu et al., 2003).

Minimum inhibitory concentration (MIC) is the lowest concentration of an antimicrobial that will inhibit the visible growth of a microorganism after overnight incubation. Minimum inhibitory concentrations are important in diagnostic laboratories to confirm resistance of microorganisms to an antimicrobial agent and also to monitor the activity of new antimicrobial agents. MIC can be helpful in establishing the level of resistance of a particular bacterial strain and can substantially affect the decision to use certain antimicrobial agents. Minimum
Inhibitory Concentration (MIC) test is a well-established assay for the biostatic (growth-inhibiting) activity of liquid antimicrobials. It is rapid, relatively inexpensive, and reliable. The MIC method measures the effect of decreasing concentrations of antiseptic over a defined period of time in terms of inhibition of microbial population growth. The concentration of drug required to produce the effect is defined as the Minimum Inhibitory Concentration and is normally several hundred to thousands of times less than the concentration found in the finished dosage form.

Minimum Inhibitory Concentration (MIC) testing define a test material's potency in terms of the concentration at which it will inhibit growth of (Minimum Inhibitory Concentration, or MIC) or completely kill (Minimum Bactericidal Concentration, or MBC) $1 \times 10^{6}$ (one million) challenge microorganisms during a 18 to 20 hour period of incubated $\left(35 \pm 2^{\circ} \mathrm{C}\right)$ exposure. Currently, there are a few web-based, freely accessible MIC databases. Clinicians use MIC scores to choose which antibiotics to administer to patients with specific infections and to identify an effective dose of antibiotic. This is important because populations of bacteria exposed to an insufficient concentration of a particular drug or to a broad-spectrum antibiotic can evolve resistance to these drugs. Therefore, MIC scores aid in improving outcomes for patients and preventing evolution of drug-resistant microbial strains. The MIC test can be done on a very small scale without using too much antimicrobial agent. This is important for experimental antimicrobials such as biologically synthesized antimicrobial peptides (Bhagat Singh and Renu Singh., 2011). 


\section{Materials and Methods}

\section{Preparation of Peptide Stock solution}

\section{Activation of Culture}

Activation of Lactobacillus helveticus NCDC 292, culture was done using MRS broth which is specific for Lactic Acid Bacteria. Five $\mathrm{ml}$ of MRS broth was taken in $15 \mathrm{ml}$ test tube in duplicate. After sterilization, it was cooled at room temperature. The lyophilized ampoule of $L$. helveticus was broken aseptically in laminar air flow and small amount (one loop full) of the dried culture was transferred into tube containing MRS broth. It was mixed properly using vortex shaker and then incubated at $37^{\circ} \mathrm{C}$ in an incubator for 24 to 48 hours. After 48 hours the tubes were observed for the growth and purity of culture was tested.

\section{Fermentation of milk}

Bovine milk was sterilized $250 \mathrm{ml}$ in each flask, the milk was then cooled up to room temperature and then flask were inoculated with all three @ 4.0\% and incubated at $37^{\circ} \mathrm{C}$ for a period of $24 \mathrm{~h}$ respectively. After incubation the curd was mixed properly to break large curd particles and poured in to $50 \mathrm{ml}$ autoclaved plastic tubes and centrifuged at $10,000 \mathrm{rpm} / \mathrm{min}$ at $4^{0} \mathrm{C}$ using Kubota High speed centrifuge (Japan). The supernatant obtained after filtration with $0.45 \mu \mathrm{m}$ filter was lyophilized and used with minimum amount of distilled water when required.

\section{Gel filtration}

Readymade Gel filtration column $5 \mathrm{ml}$ was purchased from Banglore Geni. The sample $2-5 \%$ of bed volume was loaded and eluted with double glass-distilled water. Double the bed volume number of fractions $1 \mathrm{ml}$ each was collected (discarded the first $5 \mathrm{ml}$ ). The presence of peptide determined by taking the absorbance at $340 \mathrm{~nm}$ Fig 1.1. The peaks obtained in G-25 chromatogram were again lyophilized and dissolved in minimal amount of double glass distilled water. Final concentration of peptide in test sample was measured using formula given below.

Sample concentration $=$ OD of Unknown $\times$ Concentration of known Standard/ OD of Sample

\section{HPLC conditions}

The reverse phase HPLC (Waters, USA) with Spherisorb C-18 column (4.6 X $250 \mathrm{~mm}$ ) with $20 \mu \mathrm{l}$ loop was used for the separation of the peptides. Gradient solvent delivery was achieved using two Water's pumps at the flow rate of $0.75 \mathrm{ml} / \mathrm{min}$. Solvent A was $0.1 \%$ Trifluoroacetic acid (TFA) in HPLC (Milli-Q) grade water. Solvent B was $0.09 \%$ TFA, $90 \%$ acetonitrile. Both the solvents were filtered using $0.45 \mu \mathrm{m}$ membrane filters and degassed before use. The C-18 column was thoroughly washed with solvent until the base line was obtained. Twenty $\mu$ of the sample was injected. Detection was monitored with Water's dual detector at 220 $\mathrm{nm}$ and $280 \mathrm{~nm}$ for all the fractions. The fractions of the respective peaks was pooled and lyophilized.

\section{Preparation of peptide dilution range}

Sterile test tubes were used to prepare dilutions to conduct the test. Tubes were closed with plastic or metal closure caps. Final dilution of peptides was made volumetrically in the broth. A volume of 100 $\mu \mathrm{L}, 50 \mu \mathrm{L}, 30 \mu \mathrm{L}, 20 \mu \mathrm{L}, 10 \mu \mathrm{L}, 5 \mu \mathrm{L}$ of each dilution was used for the test. 


\section{Preparation of Inoculums of test culture}

Inoculums of test culture was prepared by making a direct broth suspension of isolated colonies of E. coli and Staphylococcus aureus selected from an 18- to 24-hour agar plate. Test cultures were taken from reference culture of our lab. Suspension was made to achieve a turbidity having $1 \times 10^{6}$ microorganisms after 18 to 20 hour period of incubation at $37^{\circ} \mathrm{C}$.

\section{Results and Discussion}

The aim of broth and well diffusion methods is to determine the lowest concentration of the assayed antimicrobial agent i.e. peptide, that under defined test conditions, inhibits the visible growth of the bacterium being investigated. Broth dilution and agar diffusion method was used to find out the effectiveness of isolated peptide.

\section{In Broth dilution method}

Fresh culture of E. coli and Staphylococcus aureus was used in the test. These were inoculated into nutrient agar broth medium in the presence of different concentrations of peptide separately. Two $\mathrm{ml}$ of nutrient broth was taken in each tube and these were inoculated with $100 \mu \mathrm{L}, 50 \mu \mathrm{L}, 30 \mu \mathrm{L}, 20 \mu \mathrm{L}$, $10 \mu \mathrm{L}, 5 \mu \mathrm{l}$ of peptides. Control tube was containing only broth, after mixing tubes were incubated at $37^{\circ} \mathrm{C}$ for 24 hours in triplicates. Growth was measured after incubation (Fig 3.1 and Fig 3.2).

Optical density (OD) of control and other sample were taken after $24 \mathrm{hr}$ and $48 \mathrm{hr}$ respectively to determine MIC value of peptide. The broth culture was plated on agar surface to count the number of colonies in terms of $\mathrm{cfu} / \mathrm{ml}$. Table 3.1 shows that when $E$. coli was added in nutrient broth medium and incubated for 24 hours, OD was taken as 1.52 and $100 \mu 1$ peptide was added and incubated for another 24 hours, OD was 1.00 and 6.2 $\times 10^{6} \mathrm{cfu}$ per ml was count, second tube was added with $50 \mu 1$ peptide was inoculated and OD was 1.48 and colony count was 2 $\times 10^{4} \mathrm{cfu} / \mathrm{ml}$ followed by $30 \mu \mathrm{l}$ peptide inoculation with 1.63 as OD and $9.6 \times 10^{5}$ $\mathrm{cfu} / \mathrm{ml}$ was colony count. In $20 \mu 1$ peptide inoculation, OD was 1.70 and $2 \times 10^{5}$ cfu/ml was colony count followed by $10 \mu 1$ peptide inoculation with OD was taken as 1.77 and $5.4 \times 10^{6} \mathrm{cfu} / \mathrm{ml}$ as colony count and $5 \mu 1$ peptide inoculation shows 1.78 as OD and $6 \times 10^{6} \mathrm{cfu} / \mathrm{ml}$ colony count. Hence, Peptide is effective in showing antimicrobial property up to $20 \mu 1$ peptide inoculation.

When Staphylococcus aureus was added in nutrient broth medium and incubated for 24 hours with OD was taken as 1.45 and $100 \mu 1$ peptide was inoculated and incubated for another 24 hours, OD was 1.62 and count $9.2 \times 10^{4} \mathrm{cfu} / \mathrm{ml}$ was calculated. In second sample, $50 \mu 1$ peptide was inoculated and OD was 1.5 and colony count was $4.2 \times 10^{5}$ $\mathrm{cfu} / \mathrm{ml}$ followed by $30 \mu \mathrm{l}$ peptide inoculation with 1.54 as OD and $5.1 \times 10^{5}$ cfu/ml colony count. In $20 \mu 1$ peptide inoculation, OD was 1.60 and $6 \times 10^{6} \mathrm{cfu} / \mathrm{ml}$ was colony count followed by $10 \mu \mathrm{l}$ peptide inoculation with OD was taken as 1.63 and $4 \times 10^{6} \mathrm{cfu} / \mathrm{ml}$ colony count (table 3.2). For both E. coli and Staphylococcus aureus OD was decreased as amount of peptide was increased. The inhibition was seen up to addition of $20 \mu 1$ peptide and after that there was no inhibition of growth as evidenced by cell count cfu/ml after plating the suspension on an agar plate as seen in Fig 3.3.

\section{Agar well diffusion method}

In Well diffusion method nutrient agar was prepared and plated under aseptic condition. 
Table.1.1 Showing concentration of Peptides in unknown sample.

\begin{tabular}{|r|c|c|c|c|c|c|}
\hline S.No. & $\begin{array}{l}\text { Volume } \\
\text { of } \\
\text { Peptides }\end{array}$ & \multicolumn{3}{|c|}{ OD at 340 in triplicate } & $\begin{array}{c}\text { Mean } \\
\text { values of } \\
\text { OD }\end{array}$ & $\begin{array}{c}\text { Concentration } \\
\text { of peptide } \\
\text { (mg/ml) }\end{array}$ \\
\hline 1. & $100 \mu \mathrm{l}$ & 0.19 & 0.19 & 0.20 & 0.19 & 1.67 \\
\hline 2. & $50 \mu \mathrm{l}$ & 0.08 & 0.09 & 0.09 & 0.08 & 0.68 \\
\hline 3. & $30 \mu \mathrm{l}$ & 0.07 & 0.06 & 0.06 & 0.06 & 0.51 \\
\hline 4. & $20 \mu \mathrm{l}$ & 0.04 & 0.04 & 0.04 & 0.04 & 0.34 \\
\hline 5. & $10 \mu \mathrm{l}$ & 0.03 & 0.02 & 0.02 & 0.02 & 0.17 \\
\hline 6. & $5 \mu \mathrm{l}$ & 0.01 & 0.01 & 0.02 & 0.01 & 0.08 \\
\hline
\end{tabular}

Table.3.1 Showing colony count of E. coli incubated with different amount of peptide

\begin{tabular}{|c|c|c|c|c|}
\hline Sample & $\begin{array}{l}\text { OD after 24 } \\
\text { hours }\end{array}$ & $\begin{array}{l}\text { Addition of } \\
\text { Peptide }\end{array}$ & $\begin{array}{l}\text { OD after } \\
\text { 48hours }\end{array}$ & Colony Count (per ml) \\
\hline Control & 1.52 & ---- & 1.78 & $6.2 \times 10^{6}$ \\
\hline 1 & 1.52 & $100 u l$ & 1.00 & $3.0 \times 10^{3}$ \\
\hline 2 & 1.54 & $50 u l$ & 1.48 & $2.0 \times 10^{4}$ \\
\hline 3 & 1.51 & $30 u l$ & 1.63 & $9.6 \times 10^{5}$ \\
\hline 4 & 1.52 & $20 u l$ & 1.70 & $2.0 \times 10^{5}$ \\
\hline 5 & 1.52 & $10 u l$ & 1.77 & $6.0 \times 10^{6}$ \\
\hline 6 & 1.51 & $5 u l$ & 1.78 & $6.0 \times 10^{6}$ \\
\hline
\end{tabular}

Table.3.2 Showing colony count of Staphylococcus aureus incubated with different amount of peptide

\begin{tabular}{|c|c|c|c|c|}
\hline Sample & $\begin{array}{c}\text { OD after 24 } \\
\text { hours }\end{array}$ & $\begin{array}{c}\text { Addition of } \\
\text { Peptide }\end{array}$ & $\begin{array}{c}\text { OD after } \\
\text { 48hours }\end{array}$ & $\begin{array}{c}\text { Colony Count } \\
\text { (per ml) }\end{array}$ \\
\hline Control & 1.46 & ---- & 1.62 & $2.2 \times 10^{6}$ \\
\hline 1 & 1.45 & $100 \mathrm{ul}$ & 1.33 & $9.2 \times 10^{4}$ \\
\hline 2 & 1.43 & $50 \mathrm{ul}$ & 1.5 & $4.2 \times 10^{5}$ \\
\hline 3 & 1.46 & $30 \mathrm{ul}$ & 1.54 & $5.1 \times 10^{5}$ \\
\hline 4 & 1.46 & $20 \mathrm{ul}$ & 1.60 & $5.6 \times 10^{5}$ \\
\hline 5 & 1.46 & $10 \mathrm{ul}$ & 1.63 & $4 \times 10^{6}$ \\
\hline 6 & 1.45 & $5 \mathrm{ul}$ & 1.63 & $4 \times 10^{6}$ \\
\hline
\end{tabular}


Table.3.3 Inhibition of Staphlococcus aureus and E.coli by inoculation with different peptide concentration generated during fermentation with L.helveticus.

\begin{tabular}{|c|c|c|c|c|c|c|c|}
\hline S.No. & $\begin{array}{l}\text { Concentration of } \\
\text { Peptides }\end{array}$ & \multicolumn{5}{|c|}{ Zone of Inhibition Diameter (mm) } \\
\hline & & \multicolumn{3}{|c|}{ Staphyloccus aureus } & \multicolumn{3}{c|}{ E.coli } \\
\hline 1. & $100 \mu \mathrm{l}$ & 14 & 16 & 16 & 15 & 17 & 17 \\
\hline 2. & $50 \mu \mathrm{l}$ & 11 & 12 & 11 & 14 & 12 & 12 \\
\hline 3. & $30 \mu \mathrm{l}$ & 9 & 9 & 9 & 11 & 11 & 10 \\
\hline $\mathbf{4 .}$ & $\mathbf{2 0} \boldsymbol{\mu l}$ & $\mathbf{8}$ & $\mathbf{8}$ & $\mathbf{1 0}$ & $\mathbf{9}$ & $\mathbf{9}$ & $\mathbf{9}$ \\
\hline 5. & $10 \mu \mathrm{l}$ & - & - & - & - & - & - \\
\hline 6. & $5 \mu \mathrm{l}$ & - & - & - & - & - & - \\
\hline
\end{tabular}

Fig.3.1 Showing inhibition of E. coli after addition of peptide in broth culture.

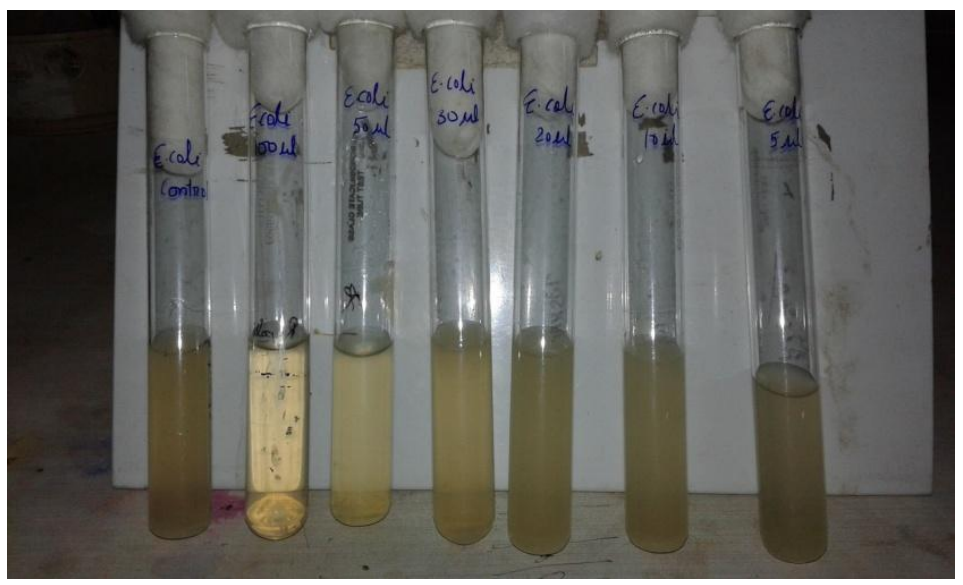

Fig.3.2 Showing inhibition of Staphylococcus aureus after addition of peptide in broth culture.

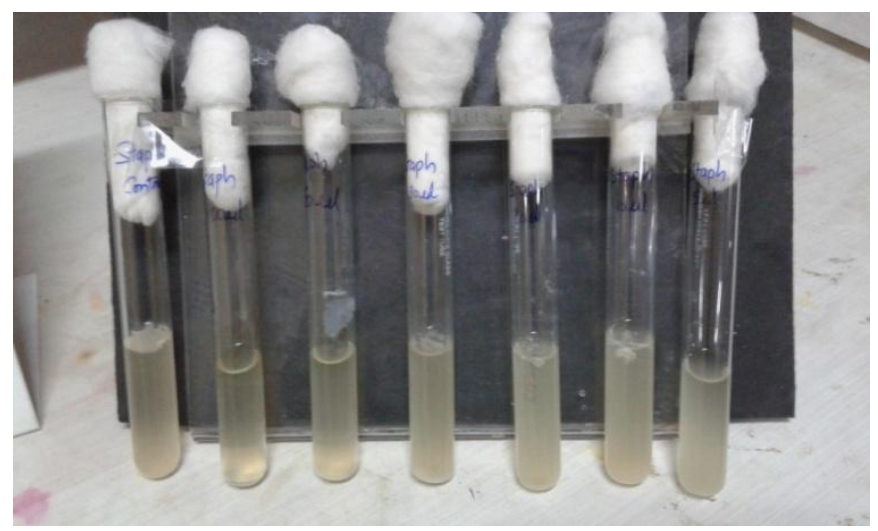


Fig.3.3 Plate showing colony count for Staphyloccocus with and without peptide inoculation

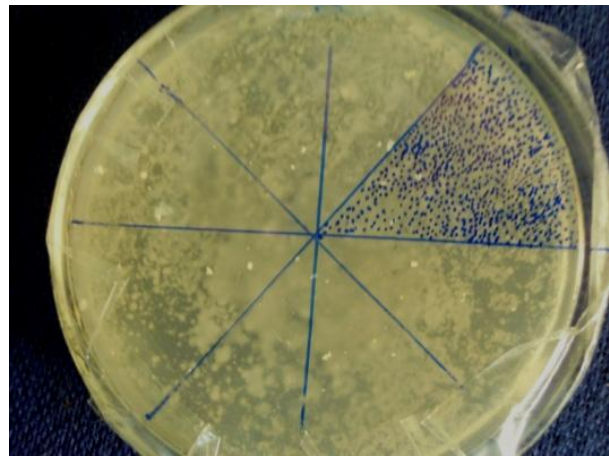

Control

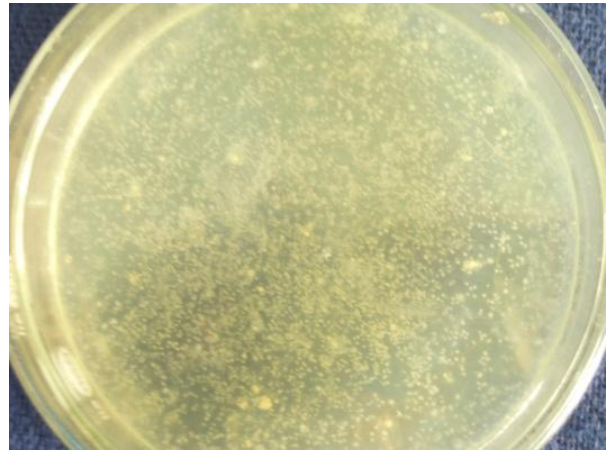

with 20 ul peptide inoculation

Fig.3.4 Showing inhibition of E. coli and Staphylococcus by $20 \mu 1$ peptide inoculation.

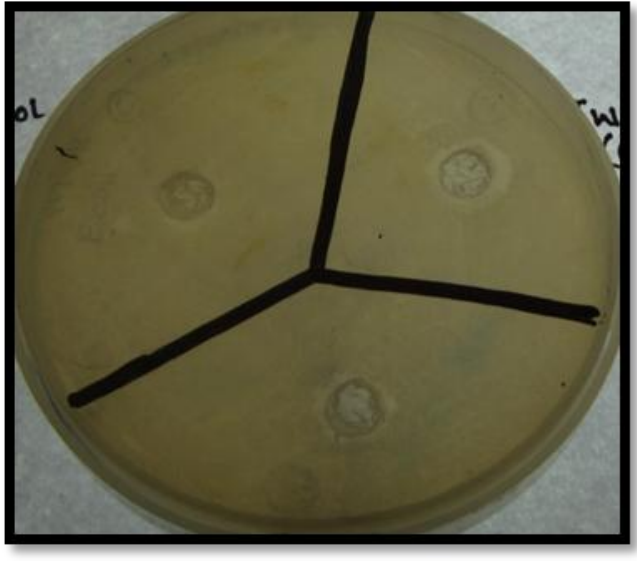

$20 \mu 1$ peptide on $E$. coli lawn

Using $7 \mathrm{~mm}$ diameter agar medium well cutter wells were made at equal distance. A drop of the soft agar was dropped into the well to the seal the bottom. The test organism E.coli, Staphylococcus aureus swabbed on the respective plates. After allowing for $10 \mathrm{~min}$ setting, $100 \mu \mathrm{l}$ of peptide was added into one of the well and sterile distilled water to another well which is used as a control and 50 $\mu 1,30 \mu 1,20 \mu 1$ $10 \mu \mathrm{l}$ and $5 \mu \mathrm{l}$ of peptide was added to respective wells in plates. These plates were incubated without inverting at $37^{\circ} \mathrm{C}$ for 24 hours in triplicate. Peptide diffusion from these sources into the agar medium leads to

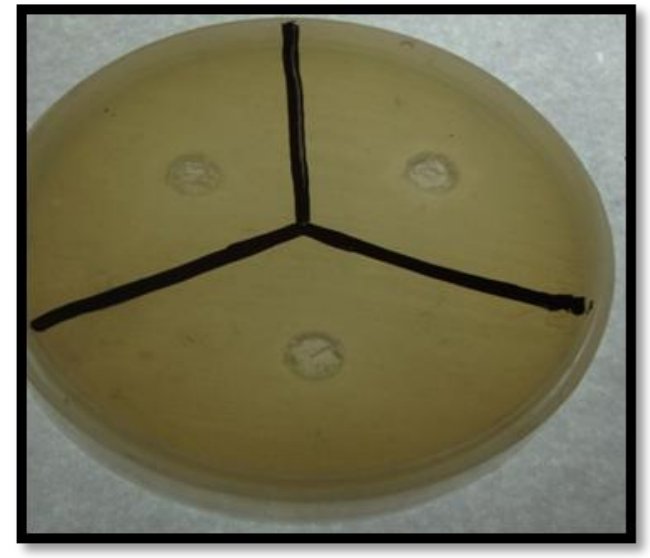

$20 \mu 1$ peptide on Staphylococcus lawn

the inhibition of bacterial growth in the vicinity of the source and to the formation of clear zones without bacterial growth.

Table 3.3 and Fig-3.4 shows $16 \mathrm{~mm}$ zone of inhibition against Staphylococcus aureus when $100 \mu$ peptide was added followed by $17 \mathrm{~mm}$ against $E$. coli. About $12 \mathrm{~mm}$ zone of inhibition found when $50 \mu \mathrm{l}$ of peptide concentration was used against $S$. aureus and $12 \mathrm{~mm}$ zone against E. coli. Plates containing $30 \mu \mathrm{l}$ of peptide concentration showed $9 \mathrm{~mm}$ Zone of inhibition against $S$. aureus and $11 \mathrm{~mm}$ against E. coli. There was no inhibition seen when $10 \mu l$ and $5 \mu l$ of 
peptide was added to the wells. Hence it is clear that $20 \mu \mathrm{l}$ of suspension containing amount of peptide was effective minimal concentration to for test organisms as observed in tube dilution and agar well diffusion method.

In conclusion, for a test to be considered valid, acceptable growth $\geq 2 \mathrm{~mm}$ button or definite turbidity must occur in the growthcontrol well. The lowest concentration at which the isolate is completely inhibited as evidenced by the absence of visible bacterial growth was recorded as the minimal inhibitory concentration or MIC. By Comparing the amount of growth in the wells or tubes containing the peptide with the amount of growth in the growth-control wells or tubes used in each set of test., hence the study demonstrated that bioactive peptides generated during fermentation with L. helveticus showed a minimum of $8 \mathrm{~mm}$ zone of inhibition against gram positive $S$. aureus and $9 \mathrm{~mm}$ against gram negative $E$. coli on plates containing $20 \mu \mathrm{l}$ peptide concentration as compared to respective plates or broth tubes which determines the lowest concentration of the assayed antimicrobial peptide will be minimal inhibitory concentration, MIC.

This study shows that higher the amount of peptide higher the inhibition. As evidenced by plates containing $20 \mu \mathrm{l}$ peptide concentration as compared to respective plates and broth tubes determine the lowest concentration of the assayed antimicrobial peptide i.e. minimal inhibitory concentration (MIC) because after $20 \mu 1$ i.e. $10 \mu 1$ and $5 \mu 1$ amount of peptide was found to have insufficient concentration of peptides to inhibit the growth of pathogens. Thus the amount of peptide concentration in $20 \mu 1$ of peptide suspension will be considered as effective minimal inhibitory concentration. The amount of peptide as calculated for $20 \mu \mathrm{l}$ peptide suspension was $0.34 \mathrm{mg} / \mathrm{ml}$ (Table1.1). Therefore we can conclude that 0.34 $\mathrm{mg} / \mathrm{ml}$ of may be considered as minimal inhibitory concentration for the inhibition of growth of $S$. aureus and E. coli. Further study and animal trials must be carried out to decide final dose of such peptide to be used for therapeutic agent or as in food preservation.

\section{References}

Agyei, D., Danquah, M.K. 2011. Industrialscale manufacturing of pharmaceutical-grade bioactive peptides. Biotechnol. Adv., 29(3): 272-7.

Andrews, J.M. 2001. Determination of minimum inhibitory concentrations, $J$. Antimicrobial Chemother., Suppl. SI, 5-16.

Bhagat Singh, Jyoti, A., Bhardwaj, G., Mehra, J., Shalander and Ahmad, S., 2012. Antimicrobial Effect of Milk Protein Derived Peptide on the Bacterial Pathogens Isolated from Urinary Tract Infections, Online Int. J. Biosolution, Vol-2 (2); 64-68.

Bhagat Singh, Rattan Chand. 2006. Antioxidative activity of bovine milk fermented with Lactobacillus helveticus, Milchwissenschaft, Vol 61 (01): 63-65

Bhagat Singh, Renu Singh. 2011. Antimicrobial effect of peptides isolated from bovine milk fermented with Lactobacillus helveticus. Milchwissenschaft, Vol-66, (3) 262265.

Erdmann, K., Cheung, B.W.Y., Schröder, H. 2008. The possible roles of foodderived bioactive peptides in reducing the risk of cardiovascular disease. $J$. Nutr. Biochem., 19(10): 643-54.

Gauthier, S.F., Pouliot, Y., Saint-Sauveur, D. 2006. Immunomodulatory peptides 
obtained by the enzymatic hydrolysis of whey proteins. Int. Dairy J., 16(11): 1315-23.

Gobbetti, M., L. Stepaniak, M. De Angelis, A. Corsetti, and R. Di Cagno. 2002. Latent bioactive peptides in milk proteins: proteolytic activation and significance in dairy processing. Crit. Rev. Food Sci. Nutr. 42: 223-239.

Kamysu, W., M. Okroj, and J. Lukasiak. 2003. Novel properties of antimicrobial peptides. Acta Biochim. Pol., 50: 236-239.

Korhonen, H., Pihlanto, A. 2006. Bioactive peptides: production and functionality. Int. Dairy J. 16, 945-960 Rajanbabu V, Chen J-Y. 2011. Applications of antimicrobial peptides from fish and perspectives for the future. Peptides 32(2): 415-20.

Sarmadi,

B.H., Ismail, A. 2010. Antioxidative peptides from food proteins: review. Peptides, 31(10): 1949-56.

Scharff, R.L. 2010. Health-related costs: from foodborne illness in the United States. Produce safety project. Available from:www.producesafetyproject.org. Accessed 2011 July 29

\section{How to cite this article:}

Garima Bhardwaj and Bhagat Singh. 2016. Potential MIC of Bioactive Peptides from Fermented Bovine Milk to Inhibit Bacterial Pathogens. Int.J.Curr.Microbiol.App.Sci. 5(11): 65-73. doi: http://dx.doi.org/10.20546/ijcmas.2016.511.007 